\title{
GABRIELA AUSTRAL: SU VIDA EN LA PATAGONLA CHILENA, DE DUSAN MARTINOVIC ANDRADE
}

\section{Begoña Alberdi Soto}

Gabriela Mistral vive en Punta Arenas entre los años 1918 y 1920, designada por el aquel entonces Ministro de Justicia e Instrucción Pública del gobierno de Juan Luis Sanfuentes, Pedro Aguirre Cerda, para ser Directora del Liceo de Niñas de esa ciudad. Respecto a su vida en esos años, sabido es el impacto que le produce a la Mistral este entorno geográfico y el reflejo de este en su imaginario poético: allí termina su libro Desolación (1922), cuestión que quedará plasmada en el tríptico "Paisajes de la Patagonia" que escenifica, en parte, su estadía en esta ciudad.

Sin embargo, poco se ha relevado la misión extraliteraria de la Mistral en Punta Arenas, pues fue enviada allí con una tarea particular: "la chilenización de un territorio donde el extranjero superabundaba" (Mistral, 1948). Luego de haber sido profesora en los liceos de Traiguén, Antofagasta y Los Andes, pero sin contar aún con el título de docente, Mistral emprende la que, en ese entonces, sería su mayor tarea en torno a la educación pública: la reorganización administrativa del Liceo de Niñas Sara Braun, que por esos años se encontraba en un estado deplorable.

El libro Gabriela Austral: Su vida en la Patagonia chilena, reconstruye la huella de la poeta en esta ciudad y enfatiza la extensión y alcances de esta labor, destacando algunas de sus más importantes acciones, tales como la campaña de alfabetización para adultos, la creación de bibliotecas populares y la publicación de la revista Mireya, semanario que recogió, para un público masivo, su poesía e ideario educativo.

Porque es en Punta Arenas donde la Mistral pondrá en práctica algunas de sus innovadoras propuestas teóricas sobre la educación y el niño o sobre las bibliotecas escolares. Al respecto, Martinovic explica el modo en que la poeta/profesora puso en práctica su teoría al desarrollar e implantar un nuevo tipo de biblioteca -escolar y no general-, dirigida por maestras y con grupos de obras seleccionadas para niños y niñas de diferentes edades (p.75).

Cada uno de los acápites de esta investigación apunta a una iniciativa y/o anécdota particular y es acompañado por valiosos documentos, tanto escritos como visuales, a través de los cuales la autora enfatiza en la labor educativa y social de la poeta en la comunidad magallánica. A modo de ejemplo, se describirá su rol docente y cultural en la Sociedad de Instrucción Popular -donde alfabetiza a un enorme grupo de mujeres excluidas de la educación formal-y se hará referencia al 
proceso de instauración de bibliotecas en un espacio completamente olvidado en los procesos de alfabetización, como las cárceles públicas.

En síntesis, Gabriela Austral constituye una valiosa e inédita investigación que rescata la labor e importancia de la poeta en el proceso de democratización de la educación en Magallanes que, desde los inicios de la historia de la nación chilena, se mantuvo por décadas en el analfabetismo y la falta de preocupación por instruir a su creciente población infantil.

En ese marco, Martinovic dará cuenta no sólo de la multiplicidad de aristas del programa de reforma educacional de la Mistral, sino que también recogerá, a través de testimonios, el impacto de estas acciones en las distintas subjetividades y colectividades locales.

\section{BIBLIOGRAFÍA}

Martinovic Andrade, Dusan. Gabriela Austral: Su vida en la Patagonia chilena. Revisión histórica (1918-1920). Fondo Nacional del Desarrollo Regional de Magallanes y Antártica Chilena, 2013.

Mistral, Gabriela. "La Antártica y el pueblo magallánico". Diario La Nación, 24 octubre, 1948. Reproducido en www.memoriachilena.cl. 